Primljen / Received: 17.11.2015. Ispravljen / Corrected: 13.9.2016.

Prihvaćen / Accepted: 10.7.2017. Dostupno online / Available online: 10.2.2018.

\section{Application of industrial by-products as mineral admixtures for self-compacting concrete}

Authors:

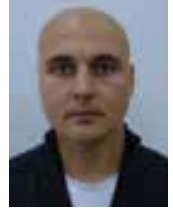

${ }^{1}$ Saša Marinković, MSc. CE marinkovic.s@mfkv.kg.ac.rs

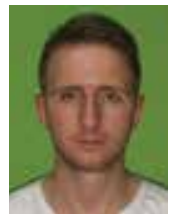

${ }^{2}$ Milan Protić, MSc. CE protic.milan@ymail.com

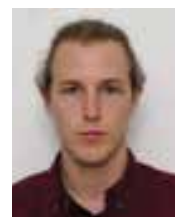

${ }^{3}$ Stepa Paunović, MSc. CE stepa.paunovic@gmail.com

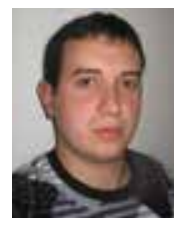

3Ivan Nešović, MSc. CE ivan.m.nesovic@gmail.com

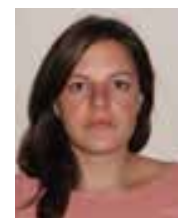

3Jelena Bijeljić, MSc. CE jelena.bijeljic@hotmail.com

${ }^{1}$ University of Kragujevac, Faculty of Mechanical and Civil Engin. ${ }^{2}$ College of Applied Technical Sciences Niš

${ }^{1}$ University of Niš, Faculty of Civil Engineering and Architecture

\section{Saša Marinković, Milan Protić, Stepa Paunović, Ivan Nešović, Jelena Bijeljić}

Professional paper

\section{Application of industrial by-products as mineral admixtures for self- compacting concrete}

Although the use of waste materials as mineral admixtures for self-compacting concrete can contribute to solving the problem of their disposal, the effect of such use should be further explored. The influence of fly ash, powdered waste brick elements roof tiles, flotation tailing and silica fume, on the consistency, compressive strength, bending tensile strength, and tensile splitting strength of concrete, is studied. Selfcompacting concrete mixtures test results are compared to a common concrete mixture.

Key words:

self-compacting concrete, mechanical characteristics of concrete, mineral admixtures, industrial by-products

Stručni rad

\section{Saša Marinković, Milan Protić, Stepa Paunović, Ivan Nešović, Jelena Bijeljić \\ Primjena industrijskih nusproizvoda kao mineralnih dodataka za samozbijajući beton}

Upotreba otpadnih materijala kao mineralnih dodataka samozbijajućem betonu može pridonijeti rješavanju problema njihovog odlaganja, ali je potrebno utvrditi njihovu djelotvornost. Ispitan utjecaj elektrofiltarskog pepela, mljevenih otpadnih opekarskih elemenata - crjepova, flotacijske jalovine i silicijske prašine na konzistenciju betona i njihove tlačne čvrstoće, vlačnu čvrstoću pri savijanju i vlačnu čvrstoću pri cijepanju. Dobiveni rezultati ispitivanja mješavina samozbijajućeg betona su uspoređeni s mješavinom konvencionalnog betona.

Ključne riječi:

samozbijajući beton, mehaničke karakteristike betona, mineralni dodaci, industrijski nusproizvodi

Fachbericht

Saša Marinković, Milan Protić, Stepa Paunović, Ivan Nešović, Jelena Bijeljić

Anwendung industrieller nebenprodukte als mineralzusätze für selbstverdichtenden beton

Die Verwendung von Abfallmaterialien als Mineralzusätze für selbstverdichtenden Beton kann der Lösung des Problems ihrer Entsorgung beitragen, aber es ist notwendig, deren Wirksamkeit festzustellen. Untersucht wurde der Einfluss von Elektrofilterasche,gemahlenerAbfallziegelelementen-Dachziegel,Flotationsabraum und Siliziumstaub auf die Konsistenz des Betons und deren Druckfestigkeit, auf die Zugfestigkeit beim Biegen und die Zugfestigkeit bei Spaltung. Die erhaltenen Ergebnisse der Untersuchungen der Mischungen selbstverdichtenden Betons wurden mit der Mischung konventionellen Betons verglichen.

Schlüsselwörter:

selbstverdichtender Beton, mechanische Betonmerkmale, Mineralzusätze, industrielle Nebenprodukte 


\section{Introduction}

Due to rapid industrial progress, an increasing attention has been directed over the past few decades toward ecological problems, and the disposal and recycling of waste materials and industrial by-products ranks among the most important problems of this kind. On the other hand, concrete is very often used as construction material and, since various materials - including industrial waste - can be added to the mixture, the addition of these materials in concrete can contribute to solving the problem of their disposal. However, in order to achieve this goal, it is necessary to find out how these materials affect characteristics of concrete, and in which proportions can they be added to the mixture so as not to disturb the desirable characteristics that make concrete such a useful building material. The aim of this paper is to examine the way in which the fly ash, powdered waste roof tiles, flotation tailing occurring in the copper production process, and silica fume, used as mineral admixtures for concrete, affect the compressive strength, flexural strength and tensile splitting strength of concrete. This, in the authors' opinion, represents a solid basis for further investigation of the wider use of these "eco-friendly" concretes in everyday construction practice. Due to an increasing use of self-compacting concrete (SCC), the conventional, vibrated concrete is being gradually pushed out of use. That is why the investigations presented in this paper focus on the influence of the above mentioned waste materials on the characteristics of SCC. The SCC mixture can be designed in various ways, but it is necessary to take care that appropriate rheological characteristics are achieved, such as the yield strength and plastic viscosity, i.e. the $\mathrm{w} / \mathrm{c}$ ratio, entrained air properties, type and quantity of small particles, etc. [1]. The influence of the mentioned materials on the consistency of fresh concrete mixtures was previously investigated. Each of these materials has a specific effect on concrete, and so each of them should be analysed in more detail.

Fly ash (FA) is very often used as an admixture to SCC. It was experimentally proven that its addition reduces the spreading time [2], porosity [3], as well as shrinkage and creep [4]. The spherical shape of particles increases the flowability and workability of concrete. The presence of fly ash slows down the reaction of alite and, consequently, the early strength of concrete is lower compared to usual values of SCC without mineral admixtures. Due to reduced porosity, concretes containing fly ash generally achieve higher final strengths [3], but this effect greatly depends on the quantity of ash added. Excessive FA content in concrete can lead to decrease in strength [5-8].

Using the powdered waste clay roof tiles (PRT) as a fine particle mineral admixture when making SCC facilitates recycling of that building material and contributes to further development of environmental concretes. Bernardinus et al. have proved that the $20 \%$ PRT content in fine particles improves characteristics of the fresh and hardened SCC considerably. Depending on mix design, this type of admixtures enables successful preparation of concretes with the strength of $40 \mathrm{MPa}$ to $60 \mathrm{MPa}$, and the slump of $65 \mathrm{~cm}$ [9]. The research results show that PRT, when used as SCC admixture, can be applied in combination with other waste materials, including waste marble particles. When combined, these two materials ensure satisfactory SCC consistency [10]. Apart from PRT, other waste materials that can be used with the same expected results are milled masonry bricks, and milled masonry elements in general. An optimum proportion of this admixture ranges from 12.5 to $37.5 \%$. [11]. The silica content, which provides pozzolanic properties to these materials, is yet another advantage of this type of waste materials [9].

A considerable quantity of waste material is generated during the copper production process. Proper storage of this material is considered to be a major environmental problem. The flotation tailing (FT), as one of the copper production process by-products, is rich in iron oxides and silicates, and is therefore suitable for concrete and mortar production. According to its chemical composition, it can be used as a supplement to Portland cement or as a substitute for smaller aggregate fractions. In this way, it is possible to solve considerable environmental problems while reaping economic benefits, reducing greenhouse gas emissions and energy required to produce the same amount of material, which contributes to preservation of natural resources [12]. Onuaguluchi and Eren have shown that concrete with the addition of FT exhibits improved mechanical properties compared to the reference concrete. The use of SCC with FT as mineral admixture increases compressive, flexural and tensile splitting strengths. An increased resistance to abrasion and smaller chloride penetration depth have also been observed. These enhanced properties have proven to be more notable when using the $5 \% \mathrm{FT}$ and a higher water-cement ratio (increased water absorption when using FT) [13]. These authors have also tested chemical effects on concrete with FT, and the corresponding results have shown that a higher presence of FT in concrete increases the resistance to acid attack, while simultaneously reducing the resistance to destructive sulphate expansion [14].

Silica fume (SF) is a by-product of silicon alloy production. It pollutes the environment and can be harmful. The addition of SF to concrete helps in solving the problem of disposal of this waste, while at the same time improving the strength of concrete. Due to its pozzolanic activity, SF can substantially improve properties of fresh and matured concrete (cohesion, strength, permeability and durability) if used in appropriate proportions. In his research, H. A. F. Dehwah shows that concrete containing $8 \%$ of quarry dust powder and $5 \%$ of SF exhibits a considerable resistance to reinforcement corrosion [15]. On the other hand, SF causes workability and consistency losses. However, according to research conducted by D. D. L. Chung, the addition of SF to concrete enhances other characteristics such as: vibration damping capacity, freeze-thaw durability, abrasion resistance of mortar, drying shrinkage, permeability, alkalisilica reactivity reduction, chemical attack resistance, and bond strength [16]. 


\section{Experiment}

An experimental study was conducted using a common vibrated concrete mixture marked $\mathrm{M}-\mathrm{R}$, and four self-compacted concrete mixtures with different mineral admixtures: fly ash, powdered waste roof tiles, flotation tailing, and silica fume. SCC mixtures were marked according to mineral admixtures used: M-FA, M-PRT, M-FT and M-SF, respectively.
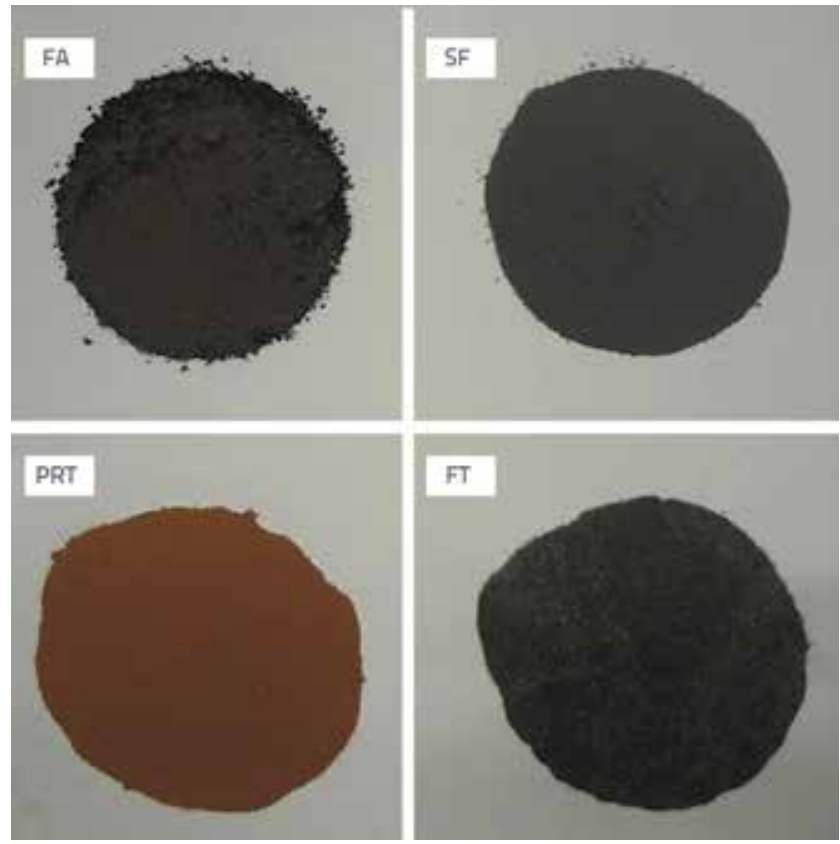

Figure 1. Mineral admixtures in self-compacted concrete

The mixtures were made using the Portland cement CEM I 52,5R produced by "Holcim" and meeting all quality requirements specified in SRPS EN 197-1 [17]. Three river aggregate fractions originating from the Vodogradnja Ltd. screening plant, Pukovac, South Morava River, were used in the preparation of mixtures $(0 / 4 \mathrm{~mm}, 4 / 8 \mathrm{~mm}$ and $8 / 16 \mathrm{~mm})$. These aggregate fractions are compliant with all quality requirements specified in EN 206: 2013 [18] and EN 12620 [19]. Fly ash originated from the Obrenovac B power plant, powdered waste roof tiles were produced by IGM Mladost Ltd. Leskovac, flotation tailing originated from the Copper Mining and Smelting Company Bor, and the silica fume Sikafume was produced by construction chemicals manufacturer Sika. Chemical composition of materials used is given in Table 1 where it is shown that the highest silicon dioxide (SiO2) proportion is contained in silica fume, and the lowest in flotation tailing. In addition, Table 1 shows that the highest percentage of compounds with pozzolanic properties (SiO2, Fe203, Al203) is contained in silica fume. The presence of other oxides is negligible. The appearance of mineral admixtures used in SCC mixtures is shown in Figure 1. The following chemical additives were used in the mixtures: Sika 3077 Viscocrete plasticizer for vibrated concrete, and TKK Srpenica Cementol Hiperplast 463 for SCC.

The composition of all mixtures used in the experiment is shown for $1 \mathrm{~m}^{3}$ of concrete in Table 2 . The mass ratios of cement, aggregate fractions and mineral admixtures were kept constant in all SCC mixtures, while masses of water (in the range of 169 to $214 \mathrm{~kg}$ for $1 \mathrm{~m}^{3}$ of concrete) and plasticizers (in the range of 2.82 to $5.64 \mathrm{~kg}$ for $1 \mathrm{~m}^{3}$ of concrete) were modified in order to fulfil the requirement of roughly the same spreading of fresh self-compacted concrete mixtures according to SRPS EN 12350-8 [20]. SCC mixtures were created using modified recommendations and guidelines of EFNARC (European Federation of National Associations Representing producers and applicators of specialist building products for Concrete) [21]. Specifications, recommendations and possible tolerances for fresh SCC properties were applied according to EN 206: 2013 [18]. The water/powder ratio (w/p) given in Table 3 was calculated as follows:

$w_{p}=\frac{m_{w}+m_{s p}}{m_{p c}+m_{m a}}$

where are:

$w_{p}$ - water/powder ratio

$\mathrm{m}_{\mathrm{w}}$ - mass of water for $1 \mathrm{~m}^{3}$ of concrete mixture [kg]

$\mathrm{m}_{\mathrm{sp}}$ - mass of plasticizer for $1 \mathrm{~m}^{3}$ of concrete mixture [kg]

$\mathrm{m}_{\mathrm{pc}}$ - mass of portland cement for $1 \mathrm{~m}^{3}$ of concrete mixture [kg]

$\mathrm{m}_{\mathrm{ma}}$ - mass of mineral admixture for $1 \mathrm{~m}^{3}$ of concrete mixture [kg]

Table 1. Chemical composition of Portland cement and mineral admixtures

\begin{tabular}{|c|c|c|c|c|c|}
\hline Component [\%] & PC & EFP & MC & FJ & SP \\
\hline $\mathrm{SiO}_{2}$ & 21.62 & 53.84 & 56.18 & 40.80 & 93.60 \\
\hline $\mathrm{CaO}$ & 60.16 & 5.15 & 6.36 & 7.36 & 0.05 \\
\hline $\mathrm{MgO}$ & 2.34 & 3.00 & 2.14 & 0.86 & 0.05 \\
\hline $\mathrm{Al}_{2} \mathrm{O}_{3}$ & 7.00 & 30.29 & 15.14 & 5.90 & 0.27 \\
\hline $\mathrm{Fe}_{2} \mathrm{O}_{3}$ & 2.60 & 3.60 & 5.57 & 41.72 & 0.21 \\
\hline $\mathrm{K}_{2} \mathrm{O}$ & 0.66 & 0.83 & 2.18 & 1.20 & 0.50 \\
\hline $\mathrm{SO}_{3}$ & 2.55 & 1.86 & - & - & 0.80 \\
\hline $\mathrm{Na}_{2} \mathrm{O}$ & 0.33 & 0.51 & 1.08 & 0.35 & 0.23 \\
\hline
\end{tabular}


Table 2. Composition of concrete mixtures for $1 \mathrm{~m}^{3}$

\begin{tabular}{|c|c|c|c|c|c|c|c|c|c|c|c|}
\hline \multirow{2}{*}{$\begin{array}{c}\text { Mixture } \\
\text { ID }\end{array}$} & \multicolumn{3}{|c|}{ Aggregate [kg] } & \multirow{2}{*}{$\mathbf{P C}[\mathrm{kg}]$} & \multicolumn{4}{|c|}{ Mineral admixtures [kg] } & \multirow{2}{*}{$\begin{array}{c}\text { Plasticizer } \\
{[\mathrm{kg}]}\end{array}$} & \multirow{2}{*}{$\begin{array}{c}\text { Water } \\
\text { [kg] }\end{array}$} & \multirow{2}{*}{$w / p$} \\
\hline & $0 / 4 \mathrm{~mm}$ & $4 / 8 \mathrm{~mm}$ & $8 / 16 \mathrm{~mm}$ & & EFP & MC & FJ & SP & & & \\
\hline$M-R$ & 825 & 308 & 587 & 398 & - & - & - & - & 3.20 & 169.0 & 0.433 \\
\hline $\mathrm{M}-\mathrm{FA}$ & 762 & 286 & 540 & 395 & 118 & - & - & - & 5.64 & 183.7 & 0.369 \\
\hline M-PRT & 770 & 288 & 547 & 403 & - & 121 & - & - & 2.82 & 210.0 & 0.406 \\
\hline $\mathrm{M}-\mathrm{FT}$ & 794 & 297 & 563 & 416 & - & - & 125 & - & 2.91 & 208.0 & 0.390 \\
\hline M-SF & 742 & 278 & 526 & 389 & - & - & - & 116 & 5.44 & 214.0 & 0.434 \\
\hline
\end{tabular}

Table 3. Properties of fresh concrete mixtures

\begin{tabular}{|c|c|c|c|c|c|}
\hline Mixture ID & M-R & M-FA & M-PRT & M-FT & M-SF \\
\hline Density of fresh concrete $\gamma_{\text {fr.con. }}\left[\mathrm{kg} / \mathrm{m}^{3}\right]$ & 2290.00 & 2290.37 & 2341.23 & 2405.43 & 2270.12 \\
\hline Slump $[\mathrm{mm}]$ & 150 & - & - & - & - \\
\hline Slump-flow [mm] & - & 650 & 680 & 655 & 630 \\
\hline $\mathrm{T}_{500}$ test $[\mathrm{s}]$ & - & 6.0 & 5.5 & 6.0 & 7.0 \\
\hline L-box test $\mathrm{H}_{2} / \mathrm{H}_{1}[\mathrm{~mm} / \mathrm{mm}]$ & - & 0.92 & 0.95 & 0.91 & 0.87 \\
\hline Sieve stability test $[\%]$ & - & 5.69 & 7.89 & 6.75 & 6.49 \\
\hline Temperature $\left[{ }^{\circ} \mathrm{C}\right]$ & 21.5 & 23.1 & 23.3 & 21.4 & 21.8 \\
\hline
\end{tabular}

\section{Test results}

The tests were performed at the Construction Materials Laboratory of the Faculty of Civil Engineering and Architecture Niš, University of Niš, Serbia. During the experiment, twelve specimens measuring $15 \times 15 \times 15 \mathrm{~cm}$ were prepared for each mixture in order to test compressive strength. Additional three specimens measuring $10 \times 10 \times 40 \mathrm{~cm}$ were made for testing flexural and tensile splitting strength.

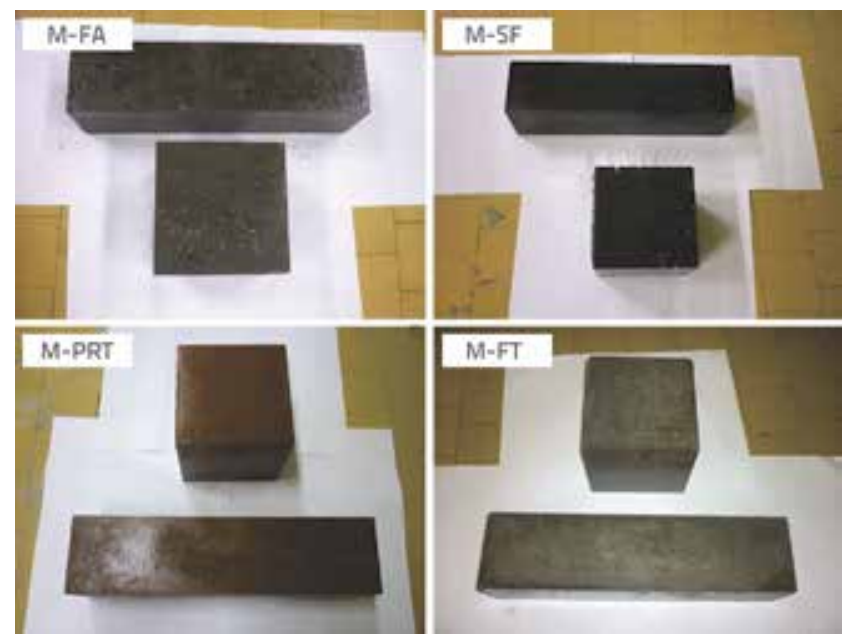

Figure 2. SCC specimens with different mineral admixtures

Thus the total number of tested specimens amounted to seventy-five. The appearance of these specimens is shown in Figure 2. Fresh SCC mixtures were tested for the following properties: density, spreading (slump-flow and $\mathrm{T}_{500}$ tests), filling and passing ability (L-box test), segregation resistance (sieve stability test) and temperature, while the standard concrete mixture was tested for: density, settlement (slump test) and temperature. The corresponding results are shown in Table 3.

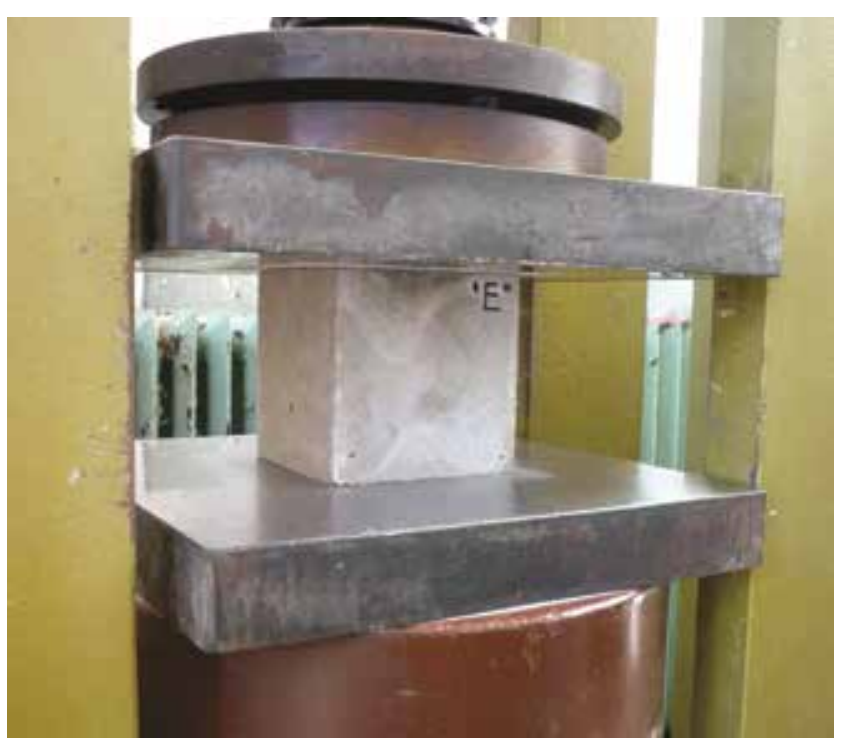

Figure 3. Testing of compressive strength

The compressive strength of concrete, measured on specimens aged 2, 7, 28 and 90 days, was determined according to SRPS EN 12390-3:2010 [22]. The testing was performed using the hydraulic press type HPM - 3000, produced by ZRMK Ljubljana (measuring range 0-3000 kN, 
Table 4. Strength test results

\begin{tabular}{|c|c|c|c|c|c|c|c|}
\hline \multirow{2}{*}{ Mixture ID } & \multirow{2}{*}{$\begin{array}{c}\text { Volume mass of ma- } \\
\text { tured concrete } \\
\gamma_{\text {mat.con. }}\left[\mathrm{kg} / \mathrm{m}^{3}\right]\end{array}$} & \multicolumn{4}{|c|}{$\begin{array}{c}\text { Compressive strength } \\
{[\mathrm{MPa}]}\end{array}$} & \multirow{2}{*}{$\begin{array}{c}\text { Flexural strength } \\
{[\mathrm{MPa}]}\end{array}$} & \multirow{2}{*}{$\begin{array}{c}\begin{array}{c}\text { Tensile splitting } \\
\text { strength [MPa] }\end{array} \\
28 \text { days } \\
\end{array}$} \\
\hline & & 2 days & 7 days & 28 days & 90 days & & \\
\hline$M-R$ & 2293.83 & 28.78 & 40.88 & 48.44 & 56.12 & 3.30 & 5.01 \\
\hline $\mathrm{M}-\mathrm{FA}$ & 2292.84 & 35.44 & 44.56 & 60.89 & 65.30 & 5.11 & 4.41 \\
\hline M-PRT & 2338.27 & 33.78 & 51.11 & 52.78 & 58.46 & 6.34 & 4.33 \\
\hline M-FT & 2407.46 & 33.78 & 44.22 & 55.34 & 60.71 & 6.47 & 3.65 \\
\hline M-SF & 2267.88 & 32.89 & 52.44 & 64.20 & 69.85 & 5.01 & 3.31 \\
\hline
\end{tabular}

accuracy $2.5 \mathrm{kN}$ ), as shown in Figure 3. The Flexural strength was determined according to SRPS EN 12390-5:2010 [23] on specimens aged 28 days. The testing was conducted using the hydraulic press WPM VEB Thüringer Industriewerk Rauenstein (measuring range 0-20000 N, accuracy 25 $\mathrm{N})$ shown in Figure 4. The tensile splitting strength was also tested on prismatic concrete specimens aged 28 days according to SRPS EN 12390-6:2012 [24]. The testing was conducted using the hydraulic press HPM - 3000 produced by ZRMK Ljubljana (measuring range $0-1000 \mathrm{kN}$, accuracy $0.5 \mathrm{kN})$.

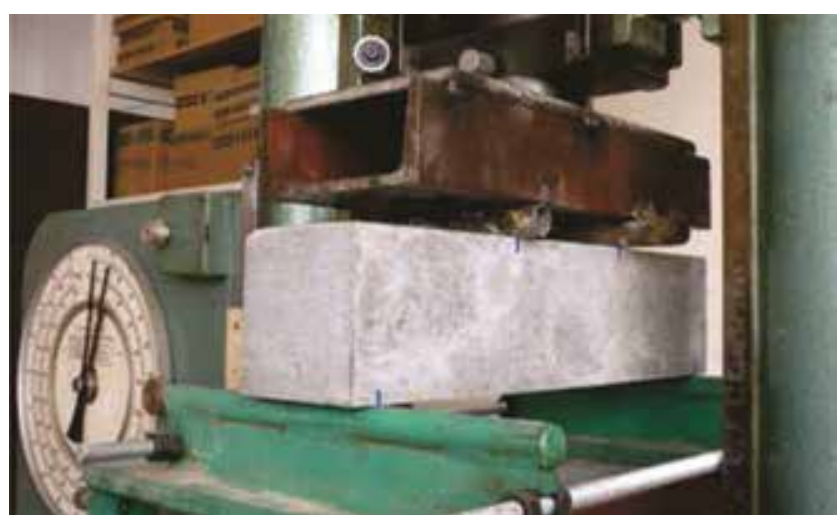

Figure 4. Testing of bending strength

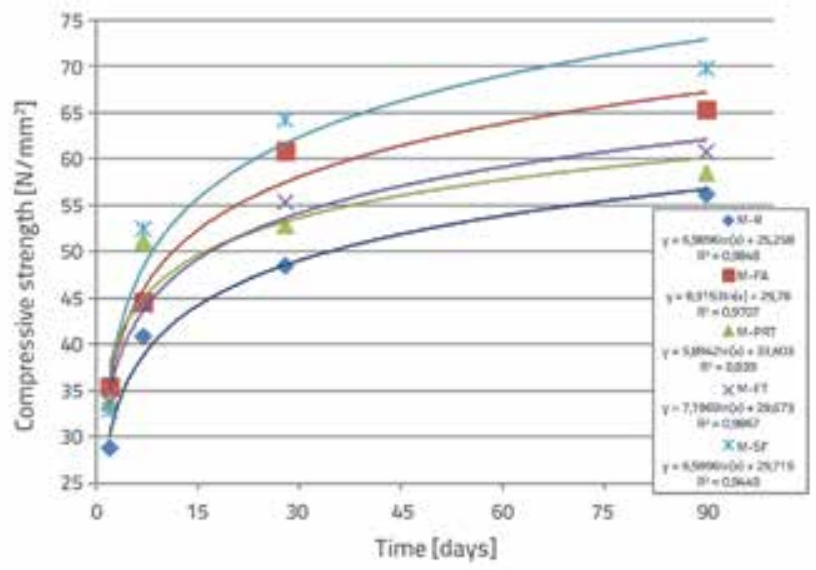

Figure 5. Changes in compressive strength over time of tested specimens
All concrete samples were matured in water chamber until the day of the testing according to SRPS EN 196-3 [25]. Test results are shown in Table 4.

The change of compressive strength values over time is shown in Figure 5 for specimens of all concrete mixtures. The correlation coefficients range from $\mathrm{R}^{2}=0.839$ (for mixture $\mathrm{M}-\mathrm{PRT}$ ) to $\mathrm{R}^{2}=0.9867$ (for mixture $\mathrm{M}-\mathrm{FT}$ ), which points to a good correspondence of functions with regard to the change of compressive strength over time.

\section{Discussion of results}

The objective of this research was to evaluate the influence of waste materials as mineral admixtures in SCC by comparing the compressive, flexural and tensile splitting strengths of SCC mixtures with equal consistencies. Also, the strength test results of SCC mixtures were compared to the common vibrated concrete mixture strengths in order to provide general public with an insight into advantages of using WMs as admixtures in the production of SCC.

\subsection{Properties of fresh SCC mixtures}

While producing SCC mixtures, the priority was to achieve equal consistencies in order to provide approximately the same conditions of placing, so that their characteristics could be mutually compared. Therefore, the mass ratios of cement, aggregate fractions and mineral admixtures were kept constant in all SCC mixtures while masses of water and plasticizers were modified.

The spreading or flowability of mixtures was measured using slump-flow and $\mathrm{T}_{500}$ tests. The slump-flow test showed that the mixture spreading varies from 630 to $680 \mathrm{~mm}$. The M-SF mixture exhibited the lowest flowability, while the highest flowability was exhibited by the M-PRT mixture. Only the M-PRT mixture belongs to class SF2 (660-750 mm). Other SCC mixtures belong to class SF1 (550-650 mm).

The $T_{500}$ test shows time in which concrete is capable of reaching the spreading diameter of $500 \mathrm{~mm}$. The $T_{500}$ time is a measure of the speed of flow and hence the viscosity. Results obtained by this test ranged from 5.5 to 7.0 seconds confirming that the M-SF mixture is the slowest (or the least 
flowable) while the M-PRT mixture is the most flowable. Although the time exhibited by the M-PRT mixture deviates from recommended values (3.5-6 s), the viscosity of this mixture is still considered good. No segregation and no water separation were observed. Time longer than 2 seconds classifies all mixtures as VS2.

The L-box test was used to determine the ability of SCC mixtures to pass through reinforced areas. This passing ability is calculated as the ratio of the height of concrete remaining at the leading edge in the horizontal section to that in the vertical section. The test was conducted with 3 reinforcing bars and the obtained results varied from 0.87 to 0.95 showing a good passing ability for all mixtures and classifying them into PL2 class (>0.8). The lowest passing ability was exhibited by the $\mathrm{M}-\mathrm{SF}$ mixture and the highest by the M-PRT mixture, which is in accordance with the spreading results.

The segregation resistance of fresh SCC was tested using the sieve stability test. The highest percentage of cement paste passing through sieve amounted to M-PRT (7.89\%) and the lowest percentage was M-FA (5.69\%). The results show good segregation resistance for all mixtures, and the passing percentage of less than $15 \%$ classifies them into the SR2 class. All fresh concrete tests showed good and similar consistency of all mixtures, with the M-PRT mixture exhibiting the highest workability in all tests. The tests confirmed that concrete containing silica fume is more cohesive and less prone to segregation, and so M-SF was the least workable mixture.

Out of all SCC mixtures, the M-SF mixture exhibited the lowest density in fresh state, while M-FT exhibited the highest density, exceeding by $5.96 \%$ that of the M-SF mixture. The highest density of the M-FT mixture can be explained by lower water absorption and lower percentage of plasticizer needed to satisfy the desired flow properties, meaning that the aggregate, cement and mineral admixture have a greater share in $1 \mathrm{~m}^{3}$ of concrete. In the same way, the lowest density of the M-SF mixture can be explained by the highest water absorption and high percentage of plasticizer, and thus the lower percentage share of aggregate, cement and mineral admixture compared to other mixtures.

\subsection{Compressive strength}

Out of all SCC mixtures, the M-FA mixture exhibited the highest 2-day compressive strength, which exceeded by $7.2 \%$ the lowest compressive strength of M-SF. The M-SF mixture had the highest compressive strength after 7 days, which exceeded by $15.7 \%$ the lowest compressive strength of the M-FT mixture. After 28 days, the M-SF mixture had the highest compressive strength and it was by $17.8 \%$ higher than the lowest strength of the M-PRT mixture. The order of strength among SCC mixtures did not change after 28 days and, after 90 days, the M-SF mixture had the highest compressive strength, which was by $19.5 \%$ higher than the lowest compressive strength of the $\mathrm{M}-\mathrm{PRT}$ mixture. The M-SF mixture had the highest compressive strength because of the highest content of $\mathrm{SiO}_{2}$, which exhibits the highest pozzolanic effect.

When SCC mixtures were compared to the common vibrated concrete, it was established that all SCC mixtures exhibit higher compressive strengths. Thus, the highest compressive strengths of SCC mixtures after 2, 7, 28 and 90 days were by $23.14 \%, 28.28 \%, 32.54 \%, 24.5 \%$ higher, respectively, compared to the vibrated concrete strengths, while the lowest compressive strengths of SCC mixtures after 2, 7, 28 and 90 days were by $14.28 \%, 8.17 \%, 8.96 \%, 4.17 \%$ higher, respectively.

\subsection{Flexural strength}

Among SCC mixtures, the M-FT mixture had the highest flexural strength after 28 days. It was by $22.57 \%$ higher compared to the $\mathrm{M}-\mathrm{SF}$ mixture, which exhibited the lowest flexural strength. The porosity reduces by replacement of some filler in the mixtures with mineral admixtures, and fine particles become additional hydration centres. This leads to better hardening of the cement paste, and to an increased flexural and tensile splitting strengths compared to concrete without mineral admixtures.

All SCC mixtures exhibited higher flexural strengths as compared to common vibrated concrete. The highest flexural strength of SCC mixtures was by $96.06 \%$ higher than that of vibrated concrete, while the lowest strength of SCC mixtures was by $51.82 \%$ higher compared to vibrated concrete.

\subsection{Tensile splitting strength}

When SCC mixtures were compared between themselves, the M-FA mixture had the highest tensile splitting strength after 28 days, exceeding by $24.94 \%$ that of the M-SF mixture, which exhibited the lowest tensile splitting strength. Various mineral admixtures have different effects on the increase in tensile strength and, at the same time, there is no direct link between the tensile strength and compressive strength. Therefore, the explanation of the noted differences in tensile splitting strength is beyond the scope of this research. The authors assume that the mentioned difference originates from the differences in microstructure of these materials but, based on the scope of examination, this cannot be fully confirmed. The said phenomenon should however be explored in greater detail, which could be the subject of some future research.

All SCC mixtures had lower tensile splitting strengths in comparison to common vibrated concrete. The highest tensile splitting strength of SCC mixtures was by $11.98 \%$ lower than that of the vibrated concrete, while the lowest strength of SCC mixtures was by $33.93 \%$ lower than the strength exhibited by vibrated concrete.

\section{Conclusion}

The primary objective of this study was to evaluate the influence of various industrial by-products when used as mineral 
admixtures for SCC. The results obtained in the scope of this study indicate the following:

- The mixture with copper flotation tailing had the highest density compared to other SCC mixtures.

- The mixture with powdered waste roof tiles had the highest workability compared to other SCC mixtures.

- The mixture with silica fume had the highest compressive strength after 28 days compared to other SCC mixtures.

- The order of compressive strengths after 28 days does not differ from the compressive strength order exhibited after 90 days.

- The mixture with copper flotation tailing had the highest flexural strength after 28 days compared to other SCC mixtures.

\section{REFERENCES}

[1] Štirmer, N., Banjad Pecur, I.: Mix design for self-compacting concrete, Gradjevinar, 61 (2009) 4, pp. 321-329.

[2] Saleh, A.R., Tahir, K.E., Kambiz, R.: Effect of various supplementary cementitious materials on rheological properties of self-compacting concrete, Construction and Building Materials, 75 (2015), pp. 89-98., http://dx.doi.org/10.1016/j. conbuildmat.2014.11.014

[3] Mnahoncakova, E., Pavlikova, M., Grzeszczyk, S., Rovnanikova, P., Cerny, R.: Hydric, thermal and mechanical properties of selfcompacting concrete containing different fillers, Construction and Building Materials, 22 (2008), pp. 1594-1600., http://dx.doi. org/10.1016/j.conbuildmat.2007.03.016

[4] Despotović, I.: Effect of different mineral supplements on the properties of self-compacting concrete, Faculty of Civil Engineering and Architecture in Niš, Dissertation, 2014.

[5] Hannesson, G., Kuder, K., Shogren, R., Lehman, D.: The influence of high volume of fly ash and slag on the compressive strength of self-compacting concrete, Construction and Building Materials, 30 (2012), pp. 161-168., http://dx.doi.org/10.1016/j. conbuildmat.2011.11.046

[6] Siddique, R.: Properties of self-compacting concrete containing class F fly ash, Materials and Design, 32 (2011), pp. 1501-1507., http://dx.doi.org/10.1016/j.matdes.2010.08.043

[7] Khatib, J., M.: Performance of self-compacting concrete containing fly ash, Construction and Building Materials, 22 (2008), pp. 19631971., http://dx.doi.org/10.1016/j.conbuildmat.2007.07.011

[8] Sukumar, B., Nagamani, K., Srinivasa, R., R.: Evaluation of strength at early ages of self-compacting concrete with high volume of fly ash, Construction and Building Materials, 22 (2008), pp. 13941401., http://dx.doi.org/10.1016/j.conbuildmat.2007.04.005

[9] Bernardinus, H., Adhi, M.S.: Self-Compacting Concrete with Recycled Traditional Roof Tile Powder, The $2^{\text {nd }}$ International Conference on Rehabilitation and Maintenance in Civil Engineering, 2013, pp. 805-816., http://dx.doi.org/10.1016/j. proeng.2013.03.074
- The mixture with fly ash had the highest splitting tensile strength after 28 days compared to other SCC mixtures.

This research has proven that the studied waste materials can be used as fillers in self-compacting concretes, which could be helpful in solving environmental problems relating to waste disposal, while also enabling preparation of concrete exhibiting better mechanical properties compared to conventional vibrated concrete. The SCC mixture with silica fume as mineral admixture has proven to be the most favourable as compared to other SCC mixtures. All SCC mixtures showed higher compressive and flexural strengths and lower tensile splitting strengths when compared to common vibrated concrete.

[10] Mohsen, T., Abderrazek, K., Mongi, B.O.: Incorporation of fillers from marble and tile wastes in composition of self-compacting concretes, Construction and Building Materials, 91 (2015), pp. 6570., http://dx.doi.org/10.1016/j.conbuildmat.2015.04.052

[11] Mohamed, N., Zohdy, K.M., Abdelkreem, M.: Mechanical, microstructure and rheological characteristics of high performance self-compacting cement pastes and concrete containing ground clay bricks, Construction and Building Materials, 38 (2013), pp. 101-109., http://dx.doi.org/10.1016/j.conbuildmat.2012.07.114

[12] Shi, C., Mayer, C., Behnood, A.: Utilization of copper slag in cement and concrete, Resources, Conservation and Recycling, 52 (2008), pp. 1115-1120., http://dx.doi.org/10.1016/j. resconrec.2008.06.008

[13] Onuaguluchi, O., Eren, O.: Copper tailings as a potential additive in concrete: Consistency, strenght, and toxic metal imobilizator, Indian Journal of Engineering \& Materials Sciences, 19 (2012), pp. 79-86., doi number is not available

[14] Onuaguluchi, O., Eren, O.: Cement mixtures containing copper tailings as an additive: durability properties, Materials Research, 15 (2012), pp. 1029-1036., http://dx.doi.org/10.1590/S151614392012005000129

[15] Dehwah, H.A.F.: Corrosion resistance of self-compacting concrete incorporating quarry dust powder, silica fume and fly ash, Construction and Building Materials, 37 (2012), pp. 277-282., http://dx.doi.org/10.1016/j.conbuildmat.2012.07.078

[16] Chung, D.D.L.: Review Improving cement-based materials by using silica fume, Journal of Materials Science, 37 (2002), pp. 673-682., doi number is not available

[17] SRPS EN 197-1: 2013. Cement - Part 1: Composition, specifications and conformity criteria for common cements, The Institute for Standardization of Serbia, 2013.

[18] EN 206: 2013. Concrete - Specification, performance, production and conformity, European Commitee for Standardization, 2013. 
[19] SRPS EN 12620: 2010. Aggregate for concrete, The Institute for Standardization of Serbia, 2010.

[20] SRPS EN 12350-8: 2012. Testing fresh concrete - Part 8: Self-compacting concrete - Slump-flow test, The Institute for Standardization of Serbia, 2012.

[21] EFNARC: Specification and Guidelines for Self-Compacting Concrete, 2002.

[22] SRPS EN 12390-3: 2010. Testing hardened concrete - Part 3: Compressive strength of test specimens, the Institute for Standardization of Serbia, 2010.
[23] SRPS EN 12390-5: 2010. Testing hardened concrete - Part 5: Flexural strength of test specimens, The Institute for Standardization of Serbia, 2010.

[24] SRPS EN 12390-6: 2012. Testing hardened concrete - Part 6: Tensile splitting strength of test specimens, The Institute for Standardization of Serbia, 2012.

[25] SRPS EN 196-3: 2010. Methods of testing cement - Part 3: Determination of setting times and soundness, The Institute for Standardization of Serbia, 2010. 